\title{
AN ENERGY AUDIT AND OPTIMIZATION IN BAR MILL ANNEALING FURNACE
}

\author{
Mehmet Hadra $^{1}$, Ahmet Serhan Hergül ${ }^{2}$, Durmuş Kaya ${ }^{3}$, Muharrem Eyidoğan ${ }^{4}$, \\ Fatma Çanka Kiliçç*, Necmi Cemal Özdemir ${ }^{6}$ \\ 1-2-3-4-5* Kocaeli University, Technology Faculty, Department of Energy Systems Engineering, Turkey; \\ ${ }^{6}$ Kocaeli University, Engineering Faculty, Department of Electrical Engineering, Turkey; \\ *Corresponding author Fatma Canka Kilic, e-mail: fatmacanka@ hotmail.com; \\ mehmett 085@hotmail.com; serhan.hergul@kocaeli.edu.tr; durmus.kaya@kocaeli.edu.tr; \\ muharrem.eyidogan@kocaeli.edu.tr; fckilic@kocaeli.edu.tr; necmi.ozdemir@kocaeli.edu.tr; \\ Received June, 2018; Accepted July, 2018; Published January, 2019;
}

DOI: https://doi.org/10.31407/ijees9105

\begin{abstract}
Due to today's competitive conditions and rising energy prices, the efficient use of energy consumed by facilities is only possible with the energy savings that can be made by investing in time, updating the technology, optimizing operating conditions and constant controlling. In this direction, The Bar Rolling Mill authorities have started this work to detect possible energy losses on the site and to increase energy efficiency. Measurements and evaluation of the results were made on the surface insulation inspections in annealing furnace, annealing furnace flue gas and annealing furnace cooling water, compressors, compressed air lines, pumps and annealing furnace burning air fan and hydraulic motors in Bar Mill. In the studies of the measurements, each equipment and line were examined separately and necessary calculations were done. Some suggestions were made on determined points which cause energy losses, how much loss is realized through these points and necessary investments to compensate for these energy losses, the price information. In the light of these works carried out in the factory; It is possible to save a total of $1,767,120.04 \mathrm{kWh} /$ year energy and $441,780.01 \mathrm{€} /$ year saving of money. Total investment cost is 558,500.85 €. The average return on investment (ROI) for all application plans is 1.26 years. After all these improvements, $\mathrm{CO} 2$ emission values will be reduced to $1,030.23$ tons per year.
\end{abstract}

Key words: Bar Rolling Mill, Energy Efficiency, Energy-Saving, Annealing Furnace, Pump, Hydraulic Motor. 